\title{
Miranda
}

Revue pluridisciplinaire du monde anglophone /

Multidisciplinary peer-reviewed journal on the English-

speaking world

$18 \mid 2019$

Guerre en poésie, poésie en guerre

\section{The Cane by Mark Ravenhill and A Very Very Very Dark Matter by Martin McDonagh}

Performance Review

William C. Boles

\section{(2) OpenEdition}

12 Journals

\section{Electronic version}

URL: http://journals.openedition.org/miranda/18344

DOI: 10.4000/miranda.18344

ISSN: 2108-6559

\section{Publisher}

Université Toulouse - Jean Jaurès

\section{Electronic reference}

William C. Boles, "The Cane by Mark Ravenhill and A Very Very Very Dark Matter by Martin McDonagh", Miranda [Online], 18 | 2019, Online since 17 April 2019, connection on 16 February 2021. URL: http:// journals.openedition.org/miranda/18344 ; DOI: https://doi.org/10.4000/miranda.18344

This text was automatically generated on 16 February 2021

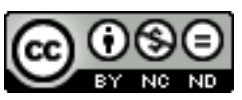

Miranda is licensed under a Creative Commons Attribution-NonCommercial-NoDerivatives 4.0 International License. 
The Cane by Mark Ravenhill and A Very Very Very Dark Matter by Martin McDonagh

Performance Review

William C. Boles

\section{Factual information about the shows}

The Cane by Mark Ravenhill-Royal Court Theatre Downstairs, December 22, 2018

Director: Vicky Featherstone

Designer: Chloe Lamford

Lighting Designer: Natasha Chivers

5 Sound Designer: David McSeveney

6 Fight Director: Bret Yount

7 Cast: Alun Armstrong, Maggie Steed, Nicola Walker 
Fig. 1

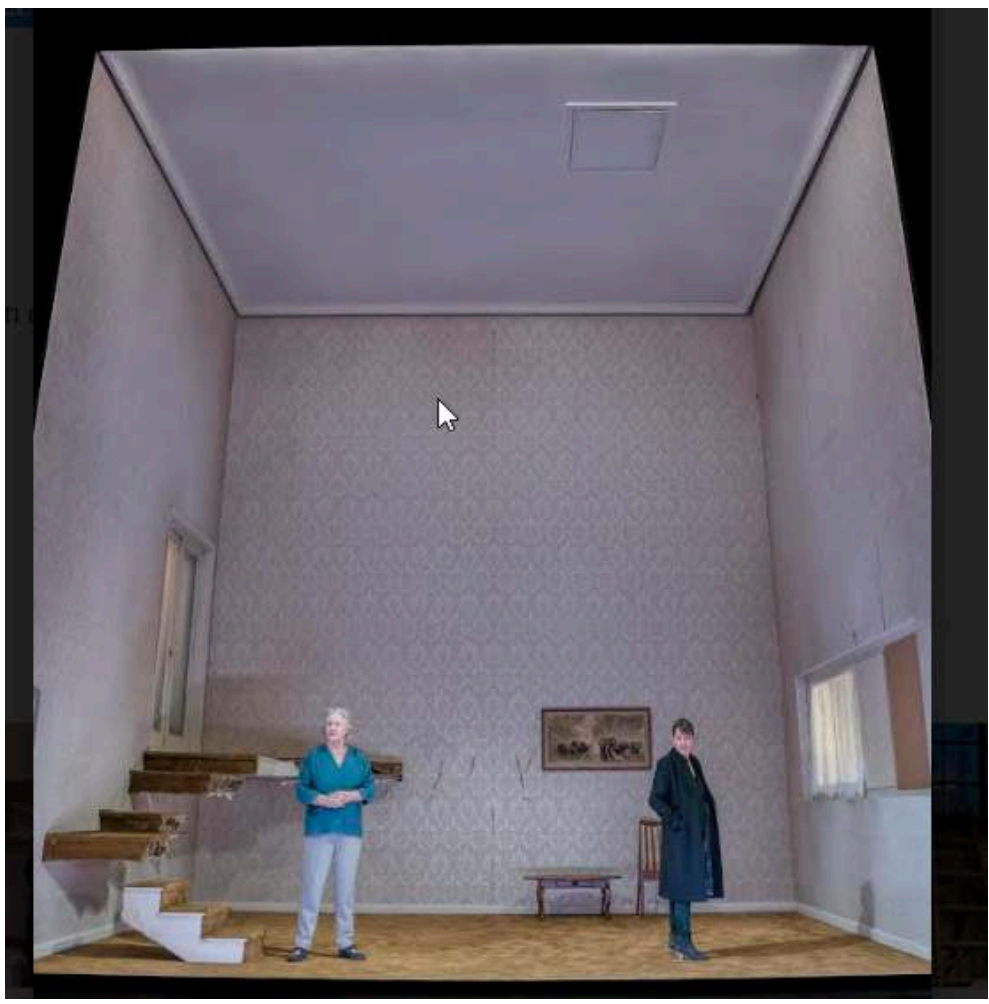

Maggie Steed as Maureen and Nicole Walker as Anna.

Credits: Johan Persson. 
Fig. 2

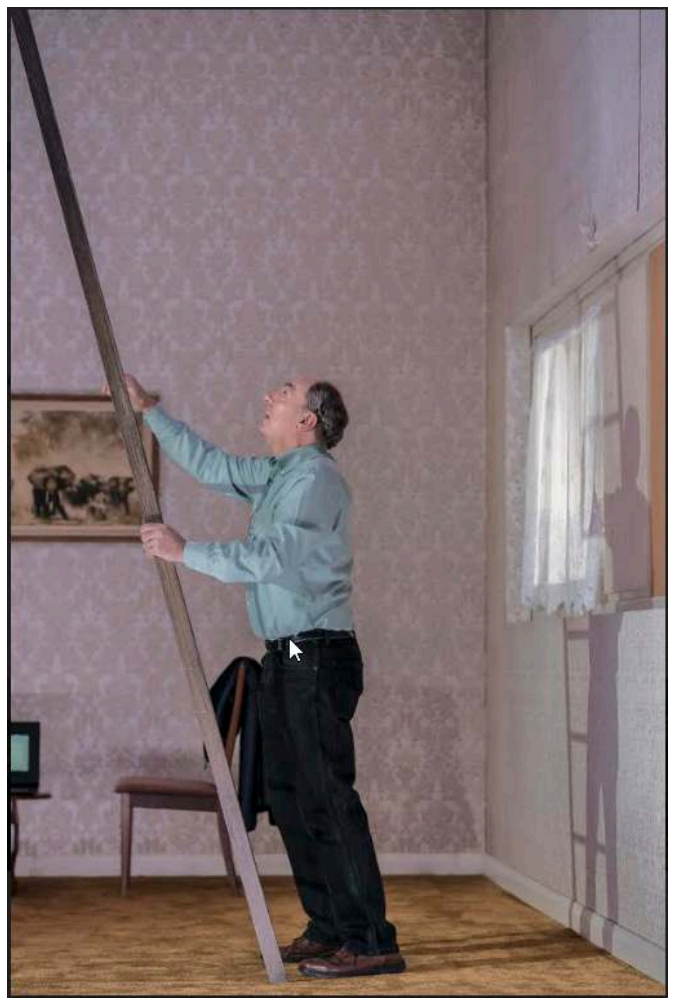

Alun Armstrong as Edward.

Credits: Johan Persson

Fig. 3

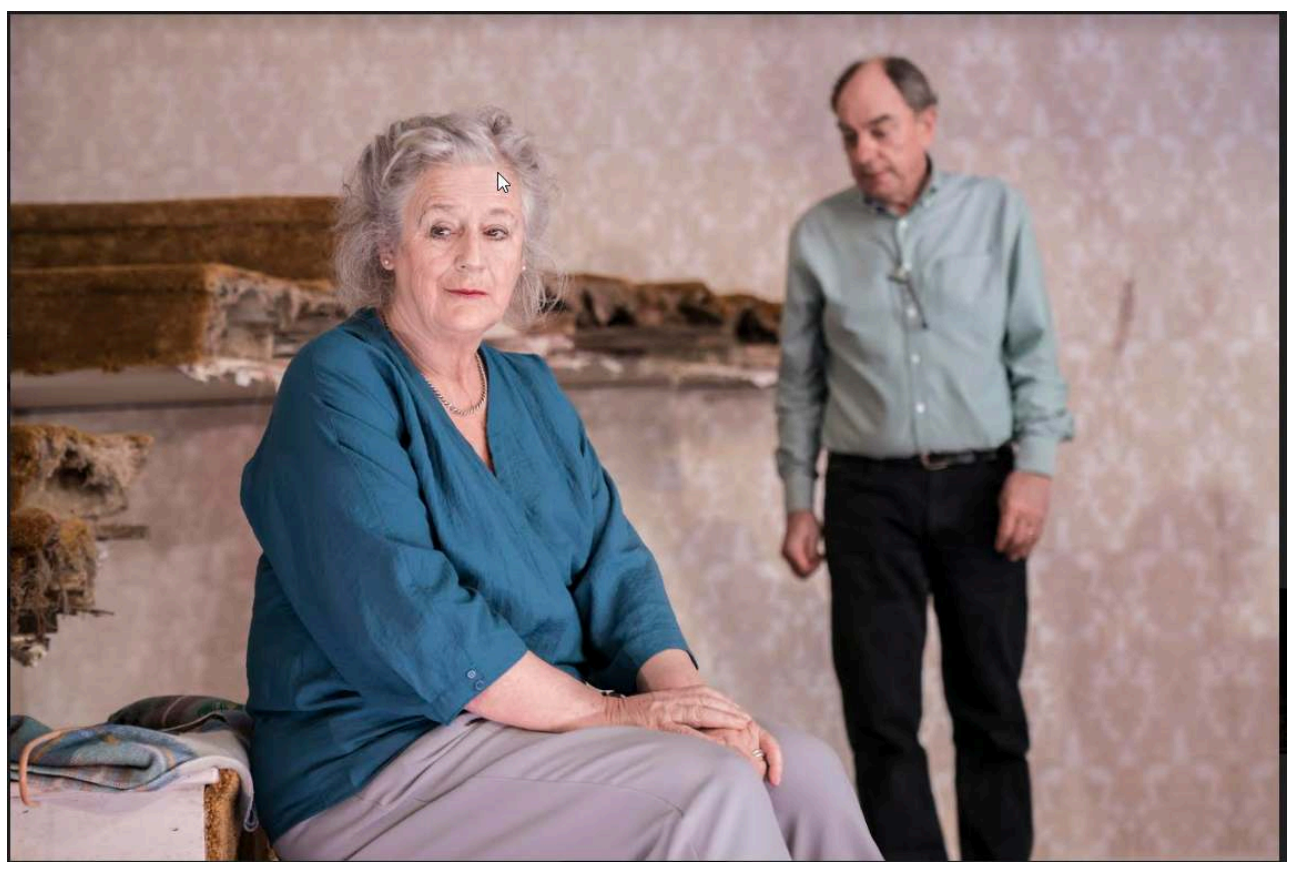

Maggie Steed as Maureen and Alun Armstrong as Edward.

Credits: Johan Persson.

8 A Very Very Very Dark Matter by Martin McDonagh-Bridge Theatre, December 22, 2018 
Director: Matthew Dunster

\section{Designer: Anna Fleischle}

Lighting Designer: Philip Gladwell

Sound Designer: George Dennis

Music: James Maloney

Illusions: Chris Fisher

Video Designer: Finn Ross

Fight Directors: Rachel Bown-Williams and Ruth Cooper-Brown, RC Annie Ltd.

Cast: Tom Waits, Johnetta Eula'Mae Ackles, Jim Broadbent, Lee Knight, Paul Bradley, Ryan Pope, Graeme Hawley, Kundai Kanyama, Phil Daniels, Elizabeth Berrington

Fig. 4

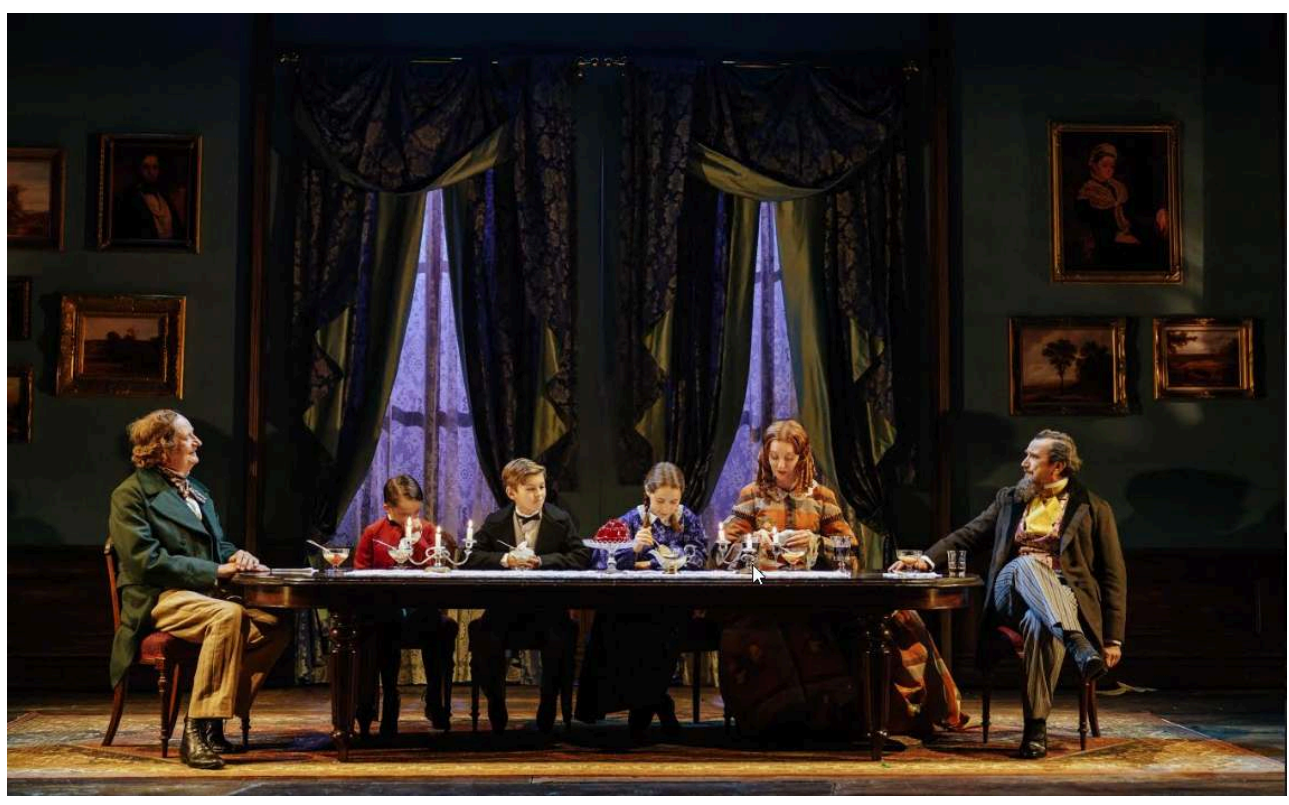

Jim Broadbent (Hans), James Roberts (Charles Jr), Regan Garcia (Walter), Audrey Hayhurst (Kate), Elizabeth Berrington (Catherine), and Phil Daniels (Dickens) (left to right).

Credits: Manuel Harlan. 
Fig. 5

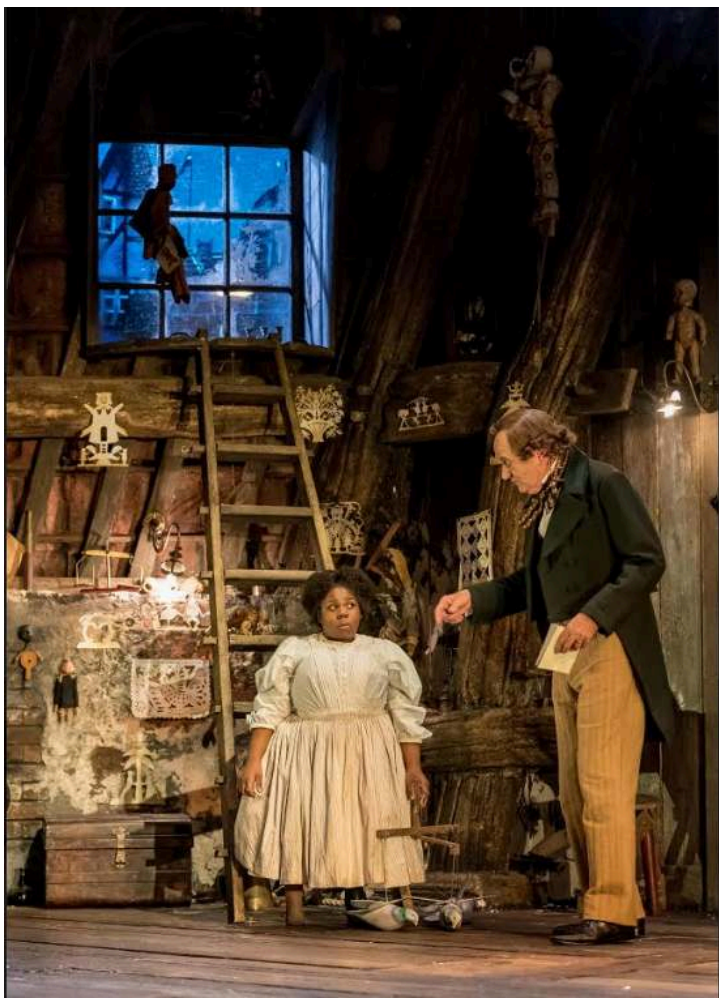

Johnetta Eula'Mae Ackles (Marjory) and Jim Broadbent (Hans) Credits: Manuel Harlan.

Fig. 6

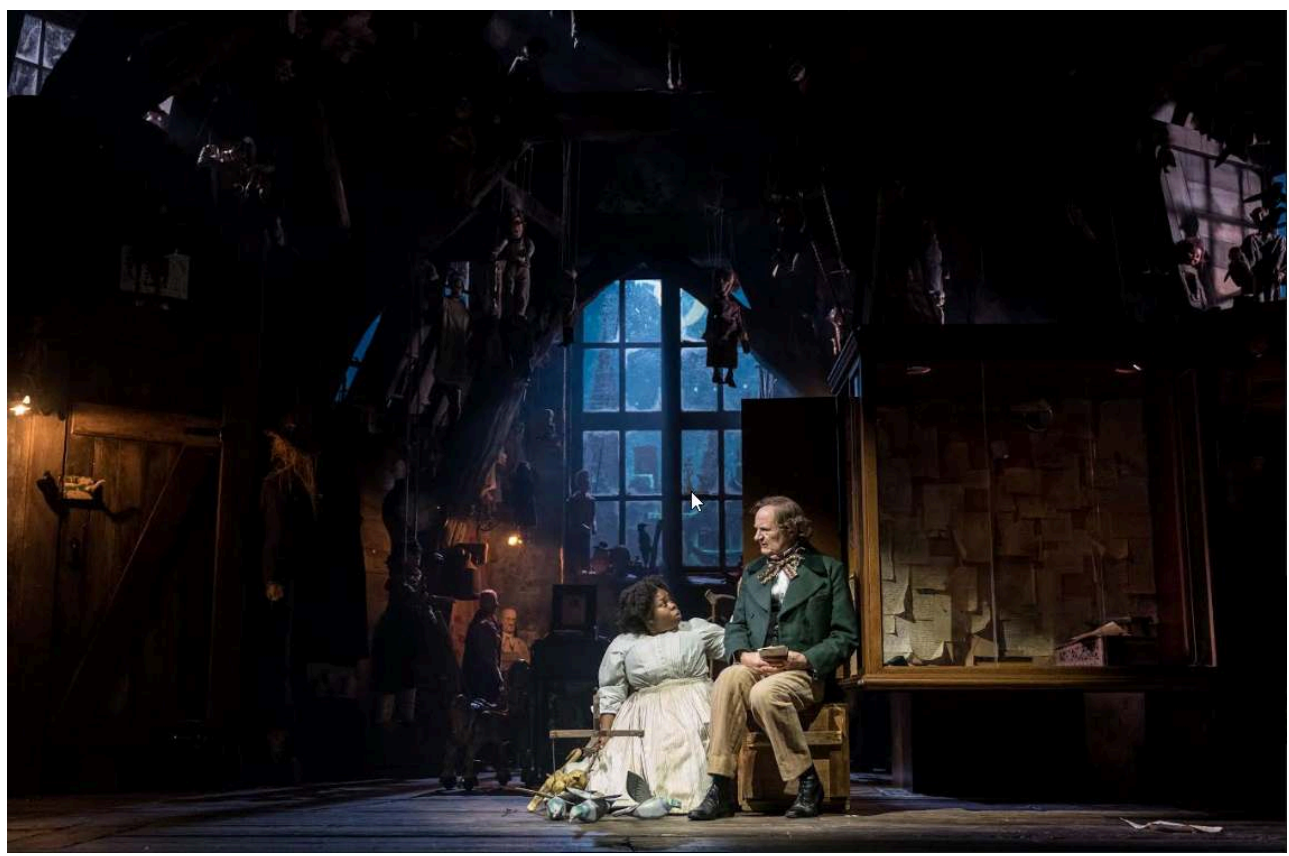

Johnetta Eula'Mae Ackles (Marjory) and Jim Broadbent (Hans)

Credits: Manuel Harlan. 


\section{Review}

During the heydays of Cool Britannia in the mid-1990s, the theatre world had numerous voices appearing on the stage, but two of the most successful figures amidst this burgeoning talent of new playwrights were Mark Ravenhill and Martin McDonagh. Ravenhill, who immediately caught the attention of the theatre world and international press, became the "it" writer because of the notoriety of his play Shopping and Fucking, which, due to refurbishments at the Royal Court, ran in the West End at the Ambassadors Theatre, placing his E-taking, rim giving, and phone sex selling characters on the same dramatic plane as The Phantom of the Opera, Agatha Christie's The Mousetrap, and the students guarding the barricades in Les Misérables. Its title, too, bestowed on it a sense of notoriety and prurient attraction, especially to the younger theatre goers, an age group that theatres were trying to (and are still trying to) attract into their spaces. The experience, a tub-thumping, techno-filled, stampede to your seat when the doors opened, brought in the crowds, brought the press coverage, provoked outrage from just about everyone under the age of 30 , and made the theatre lively and rebellious once again. Martin McDonagh's play, in some regard, existed on the other end of the spectrum from Ravenhill's. The Beauty Queen of Leenane was a one set, well-made play that harkened back to an Ireland of old, featuring a wind-swept landscape, lilting language, limited television reception, and bad biscuits, but with a twinge and a twinkle of violence, depravity, and dangerous family skirmishes. The play hinged on secrets being revealed, revenge being enacted, love being lost, and a murder leading to madness. While Ravenhill's play was embedded in the contemporary moment of the 1990s, McDonagh's was not. It could have been set just about at any time in Ireland since the end of World War II. More than twenty years later both playwrights have continued to maintain active careers as playwrights, unlike some of their theatrical peers from the 1990s, who disappeared from the boards after the In-Yer-Face movement ended. Fortuitously, in the winter of 2018 both writers had productions on at the same time in London, and, interestingly, the one-set, well-made play was now being offered by Ravenhill, while a far more playful, time-travel jumping, Tom Waits narrated, multiple set piece play was McDonagh's latest work.

Mark Ravenhill's The Cane, which finds him back at the Royal Court Theatre, is invested in two areas of interest, a bankrupt family dynamic between daughter and parents and dramatic changes taking place in the British educational system, and by the play's end both are intermingled. The play's premise is that Anna, the prodigal daughter, has returned home to visit her mother Maureen and father Edward just as protestors have begun picketing her parent's house. The reason for the demonstration is that Edward, when it was legal in the past, wielded the cane at his school, providing corporeal punishment to misbehaving boys. On the verge of a celebratory retirement from his school position this information about his former punitive actions against former students has been discovered and students have now begun to protest, sometime vociferously and vituperatively against him. While the students gather outside his home, he is trying to write a report defending his school's poor performance during its latest evaluation in hopes of it not being taken over by an educational consortium, for whom his daughter works and which is why she has returned to her childhood home after a many year absence. The piece, a 100-minute slow burn of revelatory secrets and 
recriminations, is driven through Ravenhill's attention to character development and the strength of the actors.

I must confess that being an American some of the politics behind the educational subplot of the rescinding of the school's independence was a bit foreign to me. But the comments I overheard from my fellow audience members as we left the theatre indicated that Ravenhill had captured the troubling contemporary dynamics of British school politics. Despite my ignorance on these details, the play's focus on the institutional regard for paperwork for the sake of paperwork, the glomming on to a systemic language that has no intrinsic meaning, and the ultimate uselessness of fighting the system when the fix is in is something clear to any audience member, British or not.

However, the main story line deals with the cane and its use as well as the role of violence in regard to punishments, whether it be familial or institutional. More specifically, Ravenhill is interested in violence and its lasting repercussions. The set displays that power as on the back wall there are slash marks cutting through the wall paper and wall, which we later learn happened when Anna took up an axe and went after her father in a fit of rage when she was younger. The parents, citing financial reasons, have never had the wall repaired; hence, the anger inherent in the family dynamic has remained impaled there and become a constant in Edward and Maureen's life. The director Vicky Featherstone frames the characters effectively against these slashes, as the rising linguistic violence between the family members echoes the past physical violence that occurred in the same room. The slashes on the wall, while perhaps a bit heavy handed and maybe a bit unbelievable in a practical sense, as the attack happened almost twenty-five years earlier, is effective though when considered in the light of the cane itself, which leaves behind welts on the punished student's hand. The attack on the skin parallels with the attack on the wall.

Ravenhill's play cannot be watched without recognizing its connection to the \#metoo and Time's Up movements, where a white male's previous privileged actions come back to haunt him through angry recriminations and vocal protests. Ravenhill though posits a slightly different situation. The caning of students, when Edward performed the punishments, were legal and part of the institutional rules of the school system. He was not striking the students out of his own whims and a need to exact power, which is unlike the situations of the \#metoo movement where authority figures misused their power to prey on the weak. Instead, Ravenhill goes to great narrative lengths to justify the action of the caning. Edward has spirited a book away from the school which lists every caning he did. While the list is extensive, what is stressed is the fact that each beating was signed off by Edward's headmaster and the child's own parent. These punishments then were not conducted in a vacuum. In this case Edward was merely an actor in a much larger system of discipline. His argument though falls on the deaf ears of his wife and daughter, who blame him for his involvement in those acts.

The question then becomes at whom is Ravenhill aiming the play's ire? Is it the children outside who are protesting without understanding the context of Edward's actions? Is the play attacking Anna who is angry about her father's role in the use of the cane and manipulates him to cane her at the play's end, prompting her to go outside to show the broken, bloody skin of her hand to the mob? Is it Edward who has kept this secret from his wife all these years and secretly secreted the cane in the attic for years instead of destroying it? Or is it Maureen who refuses to acknowledge the 
truth of the dire situation in which her husband finds himself through the growing protest outside their home? Ultimately, the choice is up to the audience based on their own perspective as they approach the play's subject matter. In doing so, Ravenhill provides a tantalizing dilemma that provokes the audience to dig beyond our usual knee-jerk reactions to \#metoo headlines because the deeper we dig into this family's story, the more complex the relationships and actions become with no guide to the right answer.

At one point in The Cane Edward climbs a ladder into his attic to bring down the cane that he has hidden there for many years. In Martin McDonagh's A Very Very Very Dark Matter an attic also hides a potent secret, the exposure of which will cause not only professional damage to its owner's career but also to the world's geo-politics when it comes to nineteenth century colonialism in the Congo. While Ravenhill's play is a thoughtful treatise on contemporary issues, McDonagh's play is darkly fun and an exercise in, at times, stinging silliness. A Very Very Very Dark Matter's premise is quite simple in that it posits that Hans Christian Anderson never wrote any of his child pleasing stories. Instead, locked in his attic in a three by three by three-foot box is a Congolese pygmy woman named Marjory, who writes all his stories, to which he makes the occasional superficial changes. (For example, as the play opens we discover that her most recent piece of writing for him was "The Little Black Mermaid," which he has changed to "The Little Mermaid.") Anderson, written by McDonagh to be part simpleton, part homosexual, part torturer, and part bad carpenter, relishes the successes her stories bring him, even though he cannot always correctly pronounce the words she uses to craft the stories. (The play opens brilliantly with Anderson clearly reading one of her stories for the very first time, as he shares it haltingly and at times with befuddlement before his adoring public.)

The play fractures into two narratives shortly after the play's premise is established. The first involves Anderson, who learns that Charles Dickens also has a Congolese pygmy in his attic who writes all his novels. He travels to London to confront Dickens, leaving Marjory with a few week's rations of sausages. Some of McDonagh's best comedic and acerbic writing occurs between the linguistic struggles of Anderson and Dickens to communicate, as Anderson speaks only a hilarious pidgin English as he strives to get Dickens to admit to also having a pygmy in his attic. Jim Broadbent's performance as Hans Christian Anderson was a marvel of comedic and zany energy and strikingly different from the last time he appeared in a McDonagh play, as the interrogator Tupolski he played in The Pillowman at the National Theatre.

The connection to Broadbent's previous performance is telling because one cannot help but think of The Pillowman while watching A Very Very Very Dark Matter. Both pieces share the same focus on authors and the power of storytelling, while also offering a darker secret behind the literary inspiration of the writers. Whereas Anderson never writes his stories but relies on Marjory, Katchurian had his own inspiration in the attic in the form of his tortured brother, and both authors keep their inspirations under lock and key. An oppressive government is also present in both plays. Whereas Ariel and Tupolski, representing an unnamed, fictional totalitarian government, interrogate Katchurian to discover why kids are being murdered just like in his stories, in A Very Very Very Dark Matter the Belgian government and its role in the mass murder of almost ten million Congolese drives the action of the second plot of the play, which involves Marjory. 

seems ridiculous, McDonagh ups the quotient of unpredictability by also presenting her as a time travelling Congolese pygmy woman, who has travelled to the past after having seen her family and village massacred by the Belgian invaders. She travels to the past, so that she can arm herself and return to her present to enact vengeance on those who killed her family. During her travels, though, she was unfortunately detained by Anderson and imprisoned in his attic. Also time travelling are two dead Belgian soldiers who have pursued Marjory to Anderson's attic to prevent her from murdering them in the future. (They fail, in a hail of bullets that leaves a blood splattered set). It is worth pointing out that McDonagh does not worry about explaining how this time travelling scenario works. The audience just has to accept the convention. If they do not, then it will make for a long evening for them. McDonagh even makes a joke about the confusion scenario he has created with the time travelling element, as Anderson tells Marjory that he gets confused whenever he tries to understand how she ended up in his time period.

Race has played a part in McDonagh's films-with the discussion of a race war in In Bruges and racial tensions as a driving force in Three Billboards Outside Ebbing, Missouri. Of McDonagh's plays A Very Very Very Dark Matter is the first play of his to embed itself in the issue of race, specifically in the nature of the oppression of the African population by European imperialists who looked to conquer the continent and its people in any manner possible, including the genocide of a population. In addition, he highlights the appropriation of a Congolese culture by Anderson and Dickens, who both use their Congolese prisoners' ability to tell mesmerizing stories to better themselves financially. And yet, through his use of the time travelling device, McDonagh's play suggests a possible rewrite to the mass murder of ten million Congolese citizens. After facing off with the two, time travelling assassins, Marjory escapes her bondage from Anderson and wielding the weapons she has taken from the two dead soldiers, she walks out of Anderson's attic with the expressed purpose of returning home and taking on the Belgian imperialists and saving the Congo. In a play filled with incredibly funny set pieces, perhaps the most memorable moment is this Tarantino-esque ending as she departs fully armed, seeking a potential future that will erase the cruelties enacted by King Leopold the Second's troops, much like Quentin Tarantino's Django Unchained offers a violent revision of the American South in the nineteenth century. Unlike in The Cane, where the past can return and punish those in the present, A Very Very Very Dark Matter offers the possibility that the past can be revisited with the opportunity for the future to be changed, as those who previously experienced oppression at the hands of the privileged will be given another chance to write the wrongs done to them.

\section{ABSTRACTS}

Theatre reviews of The Cane by Mark Ravenhil, directed by Vicky Featherstone (6 December 201826 January 2019, Royal Court Jerwood Theatre Downstairs-London) and A Very Very Very Dark 
Matter by Martin McDonagh directed by Matthew Dunster (12 October 2018-6 January 2019, The Bridge Theatre-London).

Critiques théâtrale de The Cane by Mark Ravenhil, directed by Vicky Featherstone (6 December 2018-26 January 2019, Royal Court Jerwood Theatre Downstairs-London) et A Very Very Very Dark Matter by Martin McDonagh directed by Matthew Dunster (12 October 2018-6 January 2019, The Bridge Theatre-London).

INDEX

Subjects: Theater

Keywords: family, gender, stories/History, politics, British theatre

Mots-clés: famille, genre, histoire/Histoire, politique, théâtre britannique

\section{AUTHOR}

WILLIAM C. BOLES

Professor

Rollins College, Florida (USA) 